\title{
ДИЈАЛОГ РЕАЛНОГ И ИРАЦИОНАЛНОГ
}

\section{Сажетак}

Тема овога рада је сагледавање реалног и имагинарног простора библиотека из аспеката архитектуре као хуманистичке науке и књижевности. Просторност је схваћена као предмет интирдисциплинарног истраживања и као место прожимања наизглед различитих аспеката и успостављања интеркултурног дијалога међу њима. Кроз компаративно истраживање и примере из књижевности и архитектонске праксе, трага се за одговором на питање у којој мери архитектура може да створи простор за уметност, а уметност простор за архитектуру и да ли постоје границе међу тим просторима.

Кључне речи: Библиотеке, простор, интердисциплинарност, култура, архитектура, књижевност

\section{1. Увод}

Феномене времена и простора људи су опажали још у најранијем периоду развоја човечанства. Мерење времена одувек им је било опипљивије од поимања простора. У каснијем развоју појам простора су сагледавали из математичког, физичког и филозофског аспекта. У античкој филозофији простором се најпре бави Парменид. За Аристотела „празнина јесте простор у којем не постоји никакво тело...оно у чему се не налази апсолутно ништа“; Платон простором сматра неограничено небиће које је услов за умно обликовање појава, а Хегел тврди да је простор „проста форма, тј. апстракција, и то апстракција непосредне спољашности“ (Енцикл. пар. 254). Савремено доба донело је мултидис-

1 Бранко Павловић, Филозофски речник, Плато, Београд, 1997. 
циплинарно истраживање простора, мада се чини да општа одредница појма „Простор је оно у чему се материја физички простире“2, не доприноси значајно схватању појма. Без обзира што су се бројне науке бавиле овом интригантном темом, простор је остао именован као „оно“, што имплицира његову недокучивост и оставља га отвореном темом за даља, у новије време посебно феноменолошка истраживања.

Узрок двоструког поимања простора у библиотекарству је постојање практичне и теоријске основе ове мултидисциплинарне науке. Библиотекарство као културна делатност простор библиотеке разматра из његовог функционалног аспекта, као услов за обављање делатности и опстанак културне установе значајне за подизање колективног нивоа свести. Теорија библиотекарства своја истраживања заснива на мултидисциплинарности, на социолошким, филозофским, културолошким и аспектима бројних других научних дисциплина.

Простор у традиционалној архитектури истовремено је реални простор грађевине и ирационални простор архитекте. Реални тродимензионални простор је, као и волумен, важан ликовни елемент, па целину чине ентеријер и екстеријер, тј. спољашњи и унутрашњи физички простор. Истраживања простора у теорији архитектуре заснована су на филозофским аспектима и њима се најчешће баве теоретичари архитектуре постмодернизма. С развојем најновијих информационих технологија, сајбер- простор је постао њихова интригантна тема.

Вишезначна сложеница библиотека развила се од грчке речи biblio у значењу књига. Појам и данас означава збирку књига, установу, зграду или просторију у којој се чувају и читају књиге; као и серију књига истог издања, едицију; али и орман у коме се чувају књиге. (Речник српскохрватскога књижевног језика, књ.1: 195). Biblio- je корен бројних речи везаних за библиотечку делатност и у савремено доба библиотекарство као мултидисциплинарну науку, па се заправо може сматрати нуклеусом мултидисциплинарног развоја једне области културе. У свом семантичком значењу појам библиотека се проширивао од књижевног на уметнички и културолошки.

Двострукост значења појма библиотека из домена архитектуре изискује и различите приступе физичком обликовању библиотечких

2 Britanica Online Encyclopedia: Space (http:/www.britannica.com/eb/article-9068962/space) 
простора. Наше прве библиотеке, уско профилисане богослужбеном наменом, организоване су у просторима манастира, на пример, па можемо говорити о ентеријеру првих српских библиотека, њиховом унутрашњем простору, а не о архитектури сакралних објеката у чијем су се окриљу стварале. Овом типу библиотека данас су најсличније световне библиотеке затвореног типа у оквиру факултета, института и различитих специјализованих установа. С развојем јавних библиотека, јавља се и потреба за смештајем њихових фондова у посебним јавним објектима, па су пројектовање наменских зграда, или пренамена постојећих објеката за смештај библиотека у домену архитектуре, а разматрање простора библиотечких здања у урбаном простору с којим се остварује физичка интеракција у домену урбанизма. Задатак архитектуре је, дакле, да креира реални спољашњи и унутрашњи, омеђени простор библиотеке у коме ће се чувати безгранични ирационални простори књижевних дела. Интеракција тих физичких и ирационалних простора одвија се на нивоу реалног у фиктивном и фиктивног у реалном, дакле на нивоу инспирације аутора књижевног дела неким реалним просторима и инспирације архитекте фиктивним архитектонским структурама изграђеним речима. Реални географски простори чешће су инспирисали настајање фиктивних и узроке вероватно треба тражити у искуственим просторима стваралаца књижевних дела. Инспирисање градитељских реалних остварења фиктивним просторима романа, бајки, прича, песама често је, посебно у постмодернистичком развоју архитектуре резултирало стварањем историјских простора. Простори сећања на стваралачко дело славних књижевних стваралаца све чешће се материјализују у комплексним архитектонским остварењима.

\section{2. Реални простори библиотека}

И реални и фиктивни простори библиотека настајали су из човекове духовне потребе да сва знања прикупи и чува на једном месту, те су током развоја човечанства настајали различити типови библиотека. 
Фондови манастирских библиотека били су смештани у посебним просторијама, као што се данас смештају библиотеке затвореног типа. У таквим библиотекама архитектура обликује простор ентеријера, што подразумева налажење решења за подове, плафоне, зидове, међуспратна повезивања, светлосне системе чија је улога да дефинишу и редефинишу простор. Полазиште је увек функција, а исход креативних решења функционалност простора библиотеке у којима је омогућено синхронизовано обављање различитих послова, али и осећај склада.

„Ако посматрамо да склад (идеја) представља спољашњу перцепцију, и да феномен (доживљај) представља унутрашњу перцепцију, онда у физичком смислу спољшња и унутрашња перцепција морају бити испреплетане. Овако гледано, доживљај неке појаве је материјал за закључивање који спаја концепт и осећање. Објективно и Субјективно се уједињују. Спољашња перцепција (интелект) и унутрашња перцепција (чула) се синтетишу у усклађивању простора, светлости и материјала“ (Хол, 1991: 4).

У библиотекарству као друштвеној науци појам простора се одређује стандардима за наменско коришћење физичког простора и опреме библиотеке. Процесом стандардизације, када је реч о физичком простору, он се омеђује и уситњава, јасно дели на просторе посебних намена за различите облике библиотечког пословања. Простор обједињавања је централни, а његова фреквентност подлога за развој комуникативног односа међу корисницима. Овај концепт просторне организованости посебно карактерише традиционалне библиотеке. Потребе библиотека нашег времена су далеко комплексније, тежи се пројектовању отворених међупростора и успостављању просторног континуитета. „Двадесет први век време је парадокса за библиотеке и библиотекаре. У претходном веку било је јасно да треба направити лепу зграду, фондом одговорити захтевима стандарда и потребама читалаца, омогућити рад стручног, предузимљивог и љубазног стручног особља - и била би створена библиотека... Док су нам се силом историјском на библиотекама рушили зидови, а наше културно национално благо истовремено оплемењивало и оптерећивало туђе књижнице, у свету су милом уклањали зидове да би их повезале информационе трансвензале." (Вранеш, 2004: 9). Нова времена, убрзани начин живљења и нове технологије донели су и веће изазове за организаторе простора, о којима се размишља интензивније и шире него у прошлости. 
Посебан изазов за архитекте представља пројектовање комплексног простора јавних библиотека. Чврстом концептуалном везом између града и његових институција културе, каква је јавна библиотека, у истом простору бавили су се бројни теоретичари из библиотечког, културолошког, филозофског, социолошког, урбанистичког и архитектонског аспекта.

Историја архитектуре потврђује да су облици библиотечких здања били изазов многих познатих и анонимних архитеката. Геометријска тела, њихове комбинације и пресеци, или у савременој архитектури виртуелни „скулптурални“ облици, били су решења форми грађевина којима је заједничко трагање за идеалним обликом простора који ће истовремено симболизовати интелектуално богатство и социјално-економски статус земље у којој се налази и могућност стварања нових индивидуалних простора за будуће интелектуалне снаге. Пажња архитеката фокусирана је и на уклапање здања библиотеке у окружење, остваривање просторног континуитета кроз јединство објекта и тла, али и на просторе повезивања унутрашњости и спољашности. Настојање на успостављању склада међу тим захтевима заправо је израз комплексности библиотеке као чувара културне баштине и савремене институције културе.

Таква трагања карактеристична су и за постмодерну теорију архитектуре и представнике деконструкције из последњих деценија 20. века. Ослањајући се на „архитектонична“ истраживања Мартина Хајдегера (Martin Heidegger) и његову идеју „очувања духа места“ своје феноменолошке теорије „места“ и „пребивалишта“ развили су Кристијан Норберг-Шулц (Christan Norberg-Schulz) и Луј Кан (Louis I.Kan) и показали нешто сасвим ново у теорији архитектуре. Канова структурална експресивност обогаћена је потом концептом опслуженог и опслужујућег простора. Био је то директан утицај на Тим 10 и на јапанске метаболисте. Тојо Ито (Тoyo Ito), Кензо Танге (Kenzo Tange), Тадао Андо (Tadao Ando) веровали су да је могућ продуктивни однос између утопијског хоризонта и друштвене стварности. Друштвене промене 60-тих и 70-их год. прошлог века и разбијање сна о држави благостања, незадовољство Тоја Ита претворило је у креативност - утопију је тражио у затвореним просторима. За Ита је архитектура 
искуство флуидног простора, а лајт мотив његовог рада ритам светла и таме, архитектура звука нефизичког простора. Удаљавајући се од Атинске повеље, Алдо ван Ајк (Aldo van Eyck) развија концепт Тима 10 „архитектонско али и урбанистичко дело морало се развијати из самог живота“. Дубок траг Алдоа ван Ајка видљив је у развоју италијанске и каталонске архитектуре. (Перовић: xxvii-xxviii). Нешто касније Бернар Чуми (Bernard Tschumi) покушава да „допре до граница струке, да открије рубове до којих се може стићи критикујући је и сучељавајући je са другим струкама“ (Перовић: XL), док Марк Вигли (Marc Wigley) „Покушава да архитектури отвори канале ка стварању филозофије, а не само да је она репрезентује, или да илуструје филозофске концепте, већ да је у стању да трасира мисаоне трајекторије осмишљавања филозофских проблема" (Перовић: XLI). Умберто Еко је својом семиотичком теоријом заснованом на кодовима извршио велики утицај на теорију архитектуре. Одређујући природу архитектуре као првенствено функционалну, напомиње да „језик архитектуре делује као облик масовних комуникација, па је примарно својство архитектуре да је функционални објекат, а секундарно својство да је симболички објекат" (Перовић: XXXV). Зато, закључује Еко, „архитекти треба да пројектују архитектонске структуре за применљиве примарне функције и отворене секундарне функције“ (Перовић: XXXVI). Применимо ли Екову теорију на библиотекарство, које такође одређује промишљање из прагматичног и теоријског аспекта, биће видљив преклапајући простор двеју наука које се на први поглед чине далеким. У утврђивању садржаја и граница и архитектонског и библиотекарског дискурса темељни елемент била је уметност. У архитектури је то уметност пројектовања функционалног објекта са његовим симболичким значењима, у библиотекарству уметност оличена у књизи, у њеном физичком обликовању и њеним фиктивним духовним књижевним просторима.

\section{3. Ирационални простори библиотека}

Ирационалне просторе су различитим облицима уметничког израза, током развоја историје уметности често стварали сликари, скулптори, литерарни ствараоци. У визуелним уметностима простор 
је бивао отворен, празан, сагледив, слободан. Ирационалне просторе књижевних дела одликују несагледивост, безграничност, непредвидивост. Они су производ пишчеве имагинације, али и читаочеве способности да читајући дело прошири замишљени простор, да створи неки свој нови, оригинални поново непредвидиви простор. У реалном архитектонски обликованом ентеријеру, на просторима полица библиотеке књижевно обликовани простори егзистирају у готово свим литерарним жанровима књижевних дела од поезије до постмодернистичког романа. У скандинавским сагама, бајкама, Дантеовој визији пакла, Павићевим хазарским пространствима, просторима вечних лутања народа Црњанског, Нушићевој соби госпође министарке, Андрићевој вишеградској касаби и тако редом, без обзира на стваралачку епоху и књижевни жанр, увек су ликови у својим егзистенцијалним просторима у оквиру фиктивних простора аутора. Просторне перцепције стварног и имагинарног простора преплићу се у свести и искуству читаоца и коначно постају једно.

У феноменолошко - методолошком приступу анализи књижевног дела Р. Ингарден у својој теорији о слојевима књижевног уметничког дела издваја слој предметности и унутар њега простор на коме се одвија радња. Реални и симболички књижевни простори могу бити носиоци бројних симболичких значења - митских, литерарних, религијских, културних, историјских...

Својим ставом да „од библиотеке опипљивих књига очекујемо постојаност и прецизност чији недостатак опраштамо библиотеци ума“( Мангел: 162) Мангел читаоца уводи у додатну димензију, у библиотеке ума, у виртуелне библиотечке просторе у којима се човек налази између традиционалног и футуристичког и из чијег ума настаје реална или фиктивна слика. Суштина виртуелног простора садржана је у могућности да се у њему буде бестелесно присутан. У савременој теорији архитектуре, највећи поборник виртуелног простора амерички архитекта Питер Ајзенман ( Peter Eisenman) нову архитектуру дефинише као „архитектуру изван ограничења класичног модела, архитектуру као независан дискурс, ослобођену значења, арбитрарну, ванвременску“. Његова теорија заснована је на филозофији франц. филозофа Ж. Делеза (Gilles Deleuze) и Ф. Гатарија (Felix Guattari), по којој се простор приближава времену и непрестано мења. 


\section{4. Реални простори библиотеке као литерарни}

Често су књижевни ствараоци инспирисани библиотеком као културним феноменом тематизовали библиотеку и њене реалне просторе претварали у фиктивне. Књижевни простори њихових дела, као носиоци вишеструких значења, враћају се кроз реалне библиотечке просторе у руке читалаца. Умберто Еко, Хорхе Луис Борхес, Алберто Мангел, Иво Андрић, Зоран Живковић... уметнички су транспоновали емпиријски или метафизички простор и преобликовали га у уметнички функционалан. Он је у њиховим делима у функцији карактеризације ликова, развоја тока радње или пут ка саопштавању универзалних истина. Стварају га на начин о коме говори Гастон Башлар у „Поетици простора“: „простор је као ејдетска слика уписан у архетипски слој свести на ганици са несвесним и побуђује се у самом чину стварања" (М. Детелић: стр. 7).

Пут кружног кретања од реалног кроз ирационални и унутар њега реалнипростор бенедиктинскеопатије из 14. века, оличену мапи библиотеке, створио је Умберто Еко (Umberto Eco) у постмодерном роману „Име руже“ и понудио га читаоцу за стварање нових личних простора и путева до самоспознаје. Архитектонски прецизно разрађен лавиринт његове библиотеке чест је мотив још у античкој књижевности. Настао је по узору на легендарну грађевину „на Кнососу, на Криту, замршене конструкције и унутрашњег распореда, са безбројним просторијама и ходницима... саградио га је Дедал за Минотаура, сина критског краља Миноса“(Р. Милосављевић: стр.83). Јунаци се кретањем дуж ходника лавиринта Екове метафикције и ишчитавањем језичких кодова срећу с делима у којима је „кодирана и запамћена одређена количина информације о времену, друштву и култури“ (Н. Петковић: стр. ?) у којима је дело настало. Кретањем јунака обликују се и смењују статичан и динамичан простор, чија је уметничка функција дочаравање емоционалног стања јунака и развој сижејне радње.

И фиктивна библиотека из Борхесове (Борхес, Хорхе-Луис Borges, Jorge Luis) кратке метафоричне приче „Вавилонска библиотека“ налази се у амбијенту лавиринта. У просторе бројних шестоугаоних библиотека смештене су све написане и све књиге које ће бити 
написане. Метафорична улога овог литерарног архитектонског простора у коме је сабрано, али недоступно све знање овога света је борхесовски начин да искаже своје виђење суштине књижевности и суштине света. Спознајом јунака приче, Борхес руши илузију да је свет ограничен и да је могуће истражити све ходнике лавиринта, али и да је број књига у библиотеци бесконачан. Библиотека је „неограничена и периодичка", и након много времена истраживања закључило би се „да се исти свесци понављају у истом нереду (који би, поновљен, био: Ред)“. Иако свесни своје пролазности, оптерећени страхом од ништавила, људи не престају да трагају за смислом - песимистичка је визија Борхесовог гледања на живот исказана и у простору песме „Чувар књига“:

„У сумњивој зори

отац мога оца спасе књиге.

Ево их у кули у којој обитавам, подсећају ме на дане који припадаху другима, туђе и древне.

Шта ме спречава да сањам да сам некад одгонетнуо мудрост и брижљивом руком нацртао симболе?

Име ми је Хсијан. Чувар сам књига које су можда последње, јер ништа не знамо о Царству и Сину неба.

Оне су ту, на високим полицама, блиске и далеке у исти мах, тајновите и видљиве као звезде. Тамо су вртови, храмови."

„Култура и васељена за Борхеса су ,истозначне, неисцрпне и бесконачне'. Можда је стога појам бесконачности, који је приспео из дубине векова, управо она метафора која је привлачила и мучила писца током читавог живота“(О. Кабачек Леонидовна: 86). 
Беспросторност, безвременост и немерљивост су српском аутору научне фантастике Зорану Живковићу били неопходан простор за смештај велике архиве људских тајни у фантастичној причи „Ноћна библиотека“. Тајне људи који су икада живели систематизоване су, информативне и неизбројиве. Јунак приче, читајући књиге позајмљене из Градске библиотеке, стицајем околности доспева у другу димензију, у помало фаустовску атмосферу библиотеке која чува „књиге живота“. Чита о себи нешто што „Нико није требало да зна. Нити је смео да зна. Али је ипак знао“. У своју причу Живковић уноси симболе из класичног библиотекарства у смислу каталогизирања и систематизовања знања, али и модернистичко негирање стваралачког реда и правила, које допушта неподударност фиктивних простора аутора и читаоца, али нуди детаљ (метафору, симбол) на коме читалац гради нову фикцију.

Догађај везан за фиктивни наративни простор школске библиотеке у приповеци „Књига“ послужио је Иви Андрићу за пројекцију снова, страхова и ноћних мора дечака који с муком долази до силно жељене књиге из библиотеке да би је потом случајно оштетио. Сећањима на сопствено детињство: „А књига, то је била велика страст и велика мука наших младих година“, Андрић је стопио своје реалне и фиктивне психолошке просторе.

„Библиотека ноћу“ Алберта Мангела је „Књига о суштинској улози библиотека у људској цивилизацији...од древног Египта и старе Хеладе до арапског света, али и од Кине и Рима па све до интернет претраживача.“ (В. Бајац: корице књиге). У поглављу „Библиотека као облик" ове књиге, пријемчиве и књижевној критици и читаоцима, Мангел разматра питање значаја реалног простора за библиотеку и образлажући га, прелази праг између спољашњег реалног и унутрашњег психолошког простора. Уводи читаоца у разматрање хармоније као феномена архитектуре у стварању библиотечког простора: „...простор у којем држимо своје књиге управља нашим односом према њима. Не читамо на исти начин ако седимо у кружном простору или у четвороугаоном, у просторији с ниском таваницом или у некој с високим забатима. Стање ума у које западамо док читамо, замишљени простор који стварамо кад се задубимо у књигу, у скла- 
ду је или супротности с физичким простором библиотеке, и на њега утиче удаљеност полица, згуснут или разређен распоред књига, оно што примамо чулом мириса и додира, као и однос светла и сенке."(А. Мангел: 117). Свој став Мангел потврђује речима Мишела Мелоа, директора Библиотеке у Бобуру у Паризу: „Библиотекар је, у некој мери, и архитект. Он гради своју збирку као здање у којем читалац мора наћи пут, открити себе, и живети“ (А. Мангел: 117).

Из низа поглавља наратива „Библиотека ноћу“ Алберта Мангела, у којима аутор сагледава библиотеку из различитих аспеката, имагинацији читаоца отвара се простор за стварање новог поглавља чију би суштину могао одражавати наслов „Библиотека као неопходност“. Јер и за познаваоца библиотеке какав је Мангел и за његовог читаоца библиотека заправо то и јесте.

\section{5. „Опросторене“ библиотеке}

\section{1. Народна библиотека Србије, Београд}

Несрећни део историје Народне библиотеке Србије истовремено је признање о значају ове институције за очување идентитета једне нације. По сценариу - уништена баштина је сигуран заборав, уништена култура нестанак идентитета и народа, спаљена је до темеља Народна библиотека на Косанчићевом венцу 6.4.1941. год. Малобројне књиге које су иза ње остале пронашле су нови дом у Народној библиотеци на Врачару. По пројекту архитекте Иве Куртовића изграђена је модерна зграда националне библиотеке 1973. Спајањем два неједнака правоугаона волумена, Куртовић је створио функционални простор грађевине за организовање изложбеног, пословног и магацинског простора. Као посебне архитектонске вредности треба истаћи кров зграде и локацију у централном градском кварту којом је библиотека постала симбол града. 


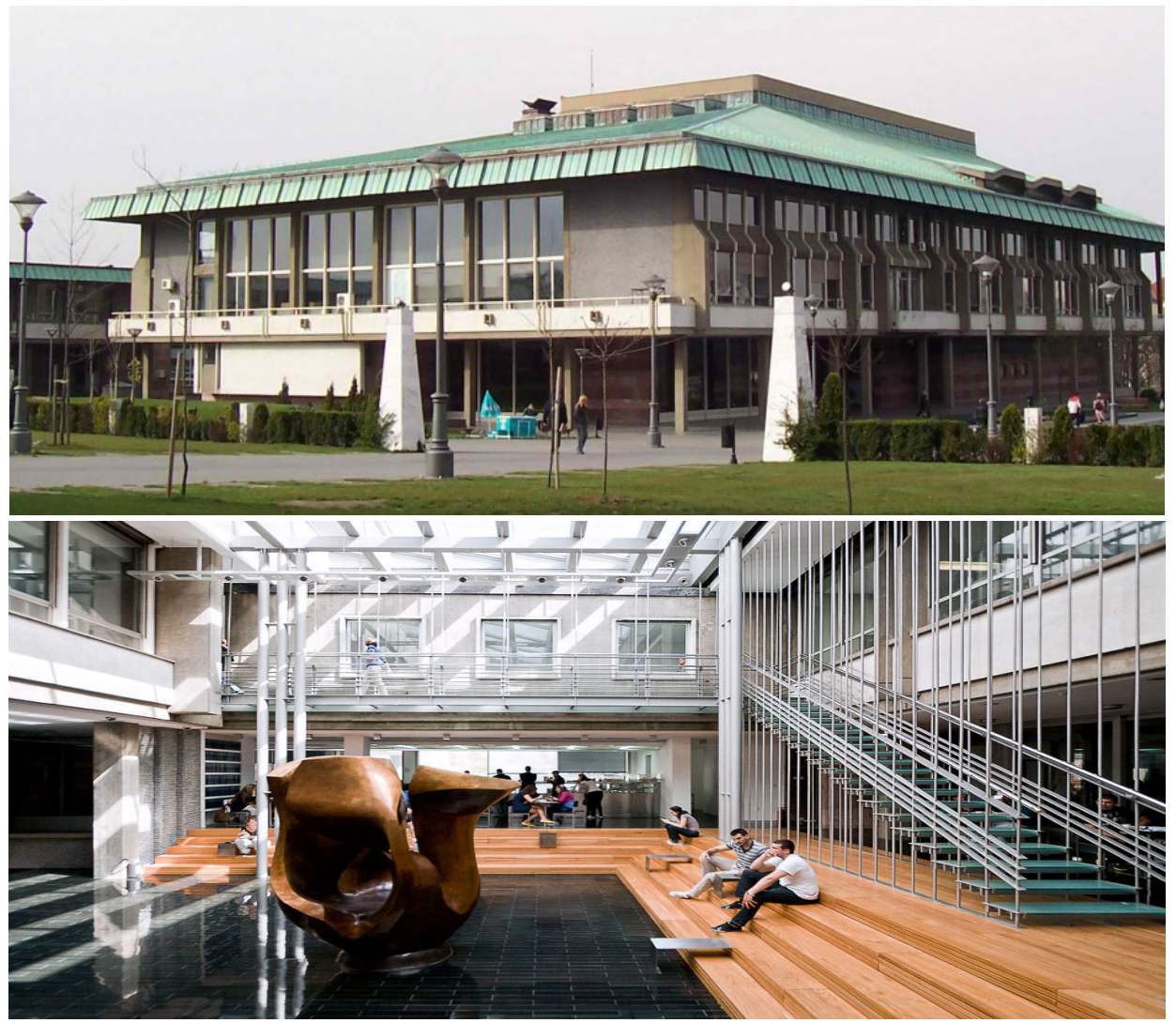

Слике 1,2. Народна библиотека Србије, Београд

Извор: (https://www.google.rs/search?q=\%D0\%BD\%D0\%B0\%D1\%80\%D0\%BE\%D0\%B)

\section{2. Библиотека у Ал Џадафу, Дубаи}

Библиотека у Ал Џадафу је пример савремене слободне скулптуралне архитектуре. Својим волуменом ова постмодерна зграда у облику огромне отворене књиге обликује простор и метафорично исказује своју намену. Реализована је „у односу масе пуног и празног, затвореног и отвореног, пластичношћу површина, волуменом облика и својом ликовношћу“.

3 Витрувије, О архитектури, стр.56 
грише различите функције реализованог простора. Осим класичне и аудио-визуелне библиотеке, унутар 66.000 квадратних метара налази се позорница, биоскопска сала, простори за предавања. Естетски и функционално интегрисани садржаји овог архитектонског објекта исказују тенденцију евалуирања библиотека новог миленијума у полифункционалне објекте, у културне центре.

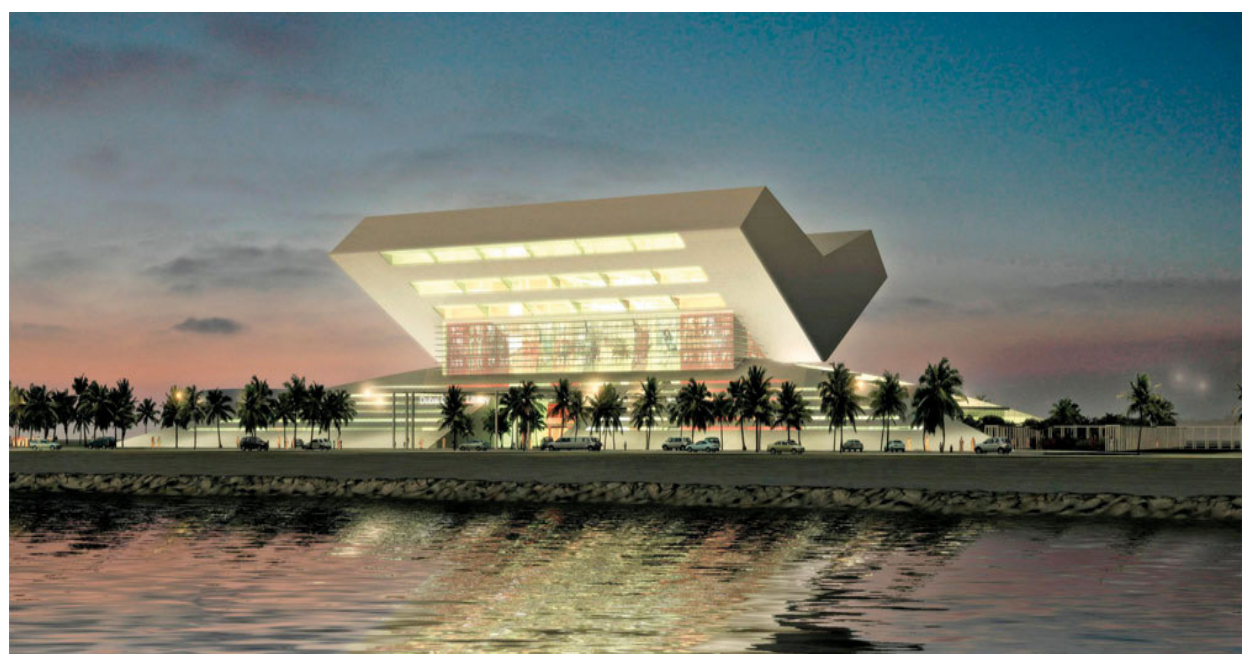

Слика 3. Библиотека у Ал Џадафу, Дубаи

Извор:(https://www.google.rs/search?q=library+al+jadaf+dubai\&source=lnms\&tbm=is ch\&sa=X\&ved=)

\section{3. Словер библиотека у Норфолку, Вирџинија, САД}

Зграда библиотеке Словер у Норфолку је успешан архитектонски спој традиционалног и модерног у историјском градском језгру, а сама библиотека симбол обједињеног класичног и савременог библиотечког пословања. Спајањем зграде старе више од једног века и суседне стаклене седмоспратнице атријумом избалансирано су спојени и простори традиционалног и савременог библиотекарства у којима равноправно егзистирају ирационални простори штампане и електронске речи, каталози традиционалног система библиотечке класификације и виртуелни линкови који до њих воде. Из архитектонског аспекта, 
реализовање успостављања односа између старе Сиборд зграде и седмоспратног крила од стаклених панела, с пресликаним унутрашњим просторима, значило је успешно спајање различитих архитектонских стилова у нови јавни простор намењен развоју образовања.
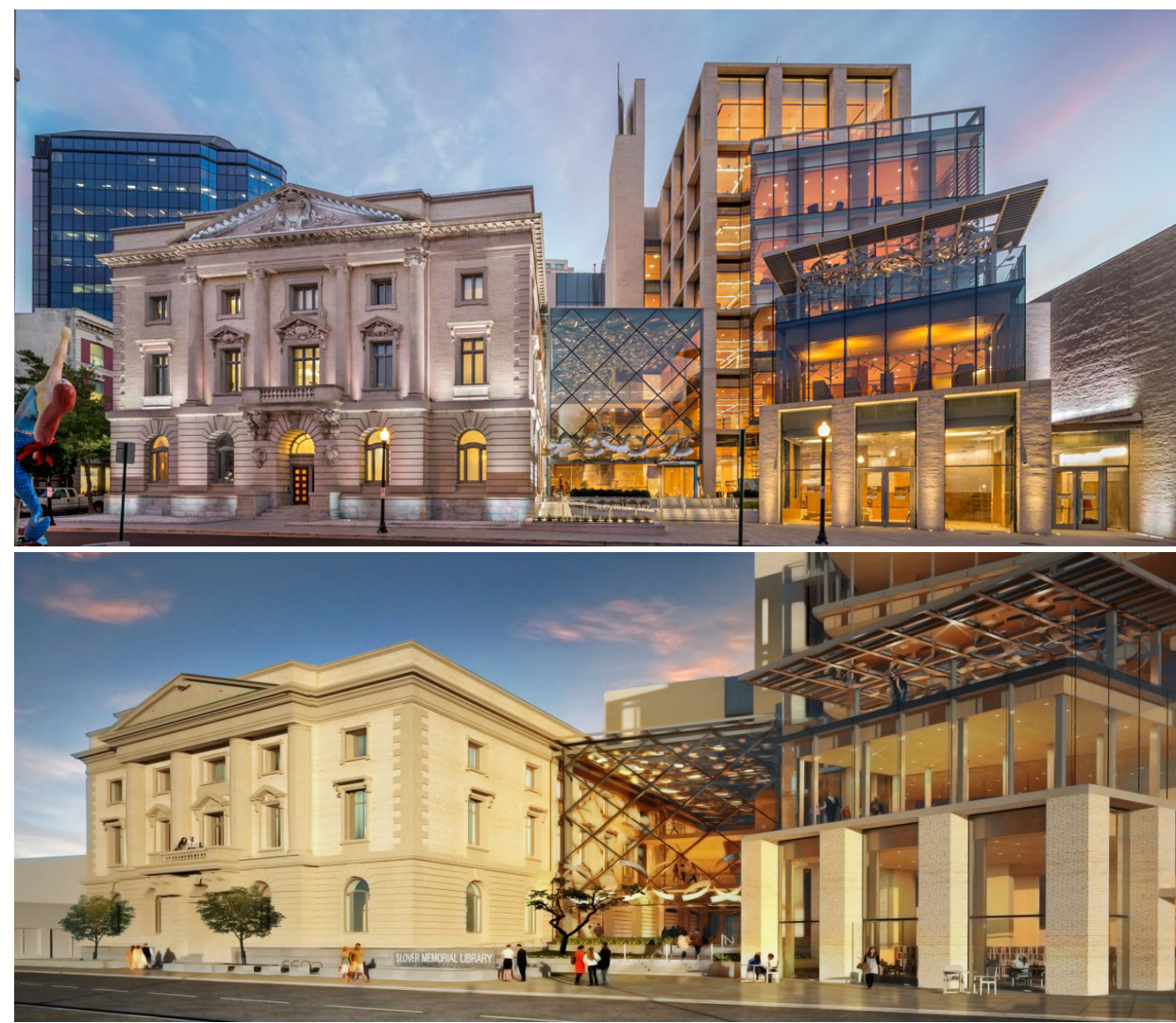

Слике 4,5. Словер библиотеке у Норфолку, Вирџинија, САД Извор: (https://www.google.rs/search?q=slover+library\&source=Inms\&tbm=isch\&sa $=X \&$ ved $=$ )

\section{4. Библиотека Joe and Rika Mansueto, Чикаго, САД}

Ова савремена и јединствена универзитетска библиотека на преко 15.000 метара квадратних доказ је да и заједнички проблем 
свих библиотека - недостатак простора за складиштење може бити инспирација за креирање нових необичних просторних решења. По пројекту архитекте Хелмута Џана (Helmut Jahn) створен је нови тип библиотеке из потребе за проширењем простора постојеће универзитетске библиотеке. Климатизовани масивни складиштени систем смештен је у подземном простору, а испод елиптичне куполе од транспарентних стаклених панела налазе се читаоница и одељење за конзервацију, рестаурацију и дигитализацију. Максимална искоришћеност простора читаонице постигнута је кружним распоредом и величином столова чије се димензије смањују ка централном делу, до испод највишег дела куполе (11 метара). Стакленом куполом са специјалном заштитом и осветљењем из металних стубова у којима су и машински системи, омогућена је адекватна осветљеност простора и током дана и током вечери. Из спољашње перспективе видљива је само купола у сачуваним зеленим површинама кампуса.

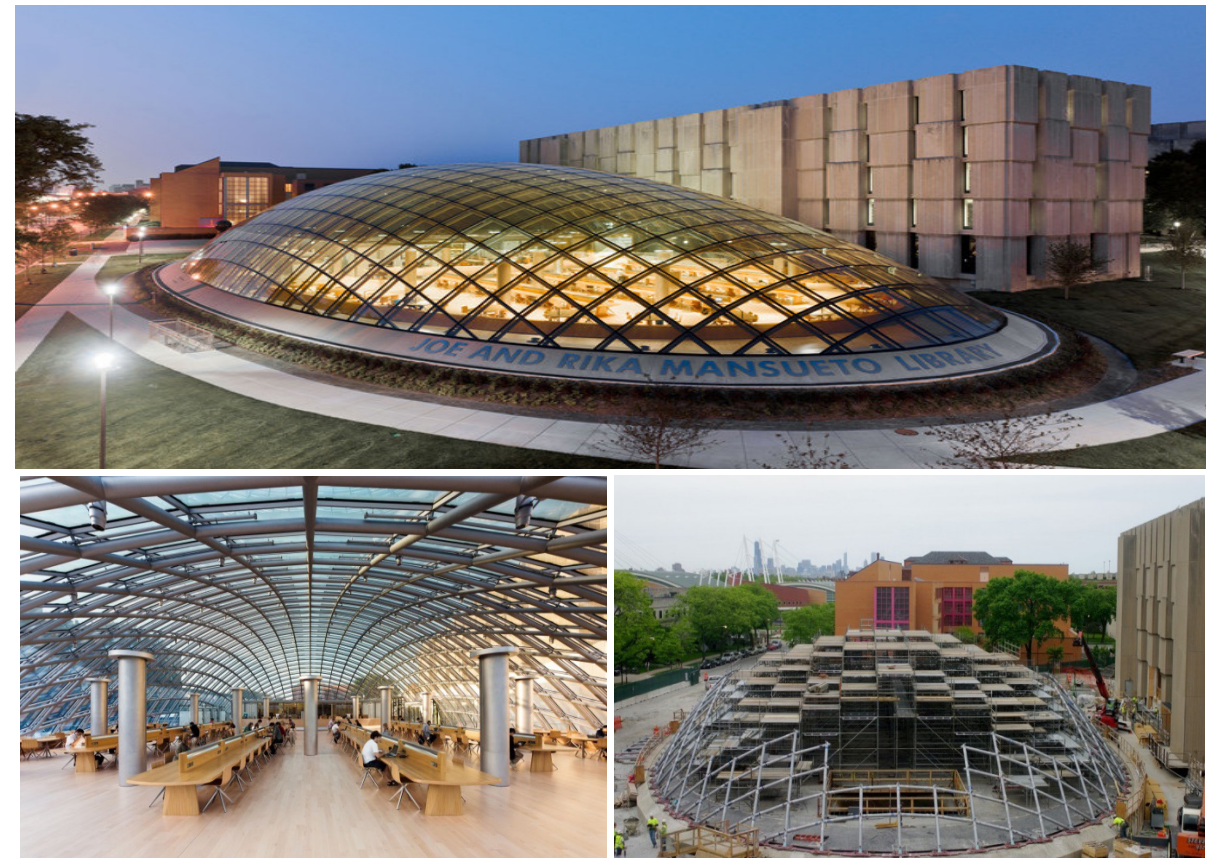

Слике 5,6. Библиотека Joe and Rika Mansueto, Чикаго, САД

Извор: (https://www.google.rs/search?q=joe+and+rika++library\&source=Inms\&tbm=is $c h \& s a=X \& v e d=)$ 


\section{5. Медијатека Сендаи, Сендаи, Јапан}

Полазна тачка пројекта архитекте Тоја Ита за Медијатеку Сендаи у Јапану била је поетична метафора плутајуће алге у текућем простору. Ито је створио отворен континуиран простор налик шуми, с нехијерархијским системом дефинисаним полицама и једноставном структуром. У слободном простору дефинисани су примамљиви простори за информисање, библиотеку, догађаје и разне друге намене. Итов циљ је био пружање могућности за социјализацију и интегрисање људи свих генерација. Коришћењем различитих врста материјала, Ито успева да простор третира као течност коју карактерише густина и може се доживети као готово опипљив феномен. Идеал простора за Ита је стопљеност архитектуре с крајоликом, концепт у коме се простор увек наставља, шири, тежи апстрактном простору. Сендаи је реализовање Итове потребе за сједињавањем физичког и вртуелног света.

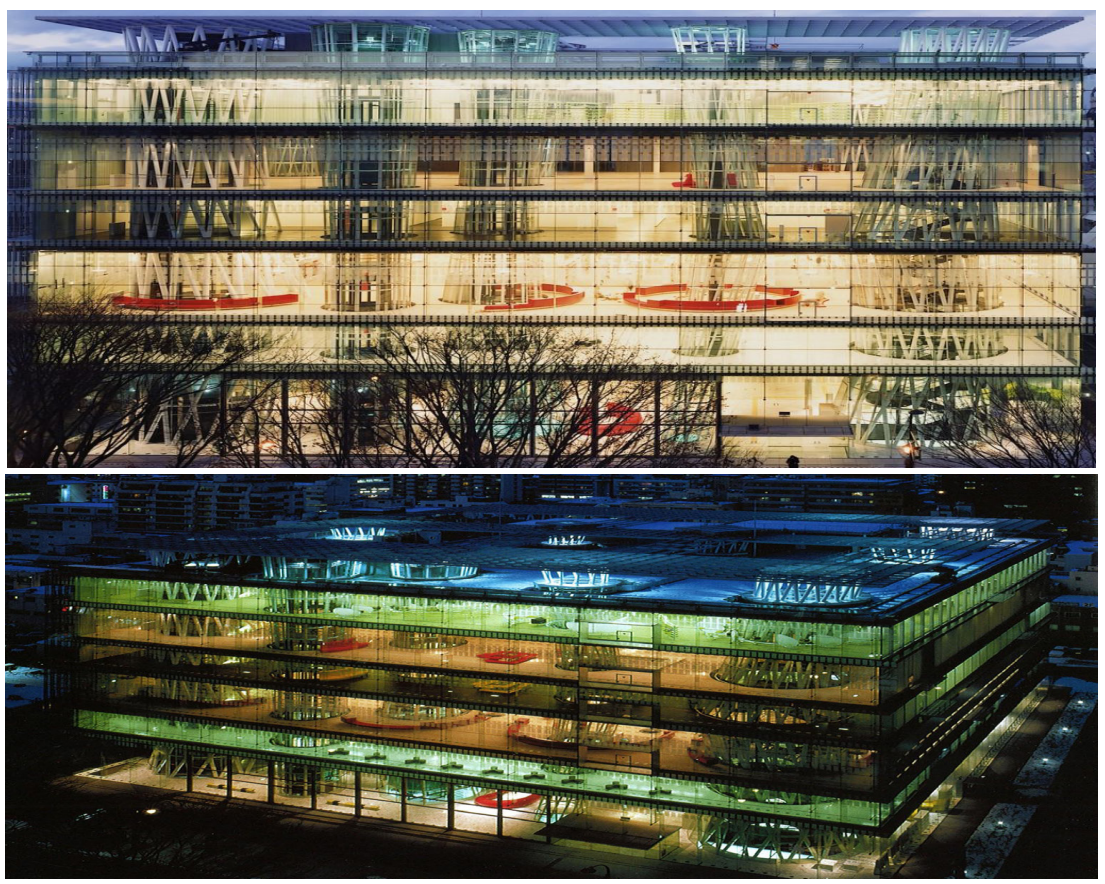

Слике 7,8. Медијатека Сендаи, Сендаи, Јапан

Извор: (https://www.google.rs/search?q=library+sendai\&source=lnms\&tbm=isch\&sa= $x \&$ ved $=0$ ahUKE) 


\section{Закључак}

У библиотекама ће увек, независно од времена и архитектонског стила који одражава културу времена њиховог настанка и којим је обликован њихов реални унутрашњи простор, егзистирати и ирационални простори књижевних дела, али и њихових читалаца, који их у домену сопственог искуства стварају и проширују новим искуствима одређујући им сопствене фиктивне границе. За разлику од реалног простора ентеријера библиотеке, омеђеног реалним екстеријером, ирационални простори су безгранични и независни, а њихово простирање немерљиво и непредвидиво. Ипак, не може се рећи да све ове врсте простора егзистирају искључиво и самостално. До њиховог преплитања долази у простору ирационалног, онда када сама библиотека постане тема књижевног дела. Тада ирационално аутора, често метафорично исказано, бива засновано на реалном искуству и у књижевном делу добија сврсисходност - основа је пишчеве имагинације али каткад и инспирација нових архитектонских остварења Кафкиним, Хамсуновим, Андрићевим делима, али и бајкама Ханса Кристијана Андерсена, на пример.

Реални и ирационални простори библиотека никада нису у опозицији, они егзистирају паралелно као јединство пространства и омеђености, истовремено се прожимају и допуњују чинећи јединствени простор стварног и имагинарног света. По заговорницима и истраживачима виртуелног простора, у основи филозофским теоријама, сви простори се спајају у један увек променљив простор у васељенским просторима ума.

\section{Литература и извори}

Eko, (2008). Ime ruže. Prevela s italijanskog Milana Piletić: Plato Books.

Mangel,A. (2008). Biblioteka noću. Prevele s engleskog Nataša Karanfilović, Nina Ivanović, Danijela Mihić: Beograd : Geopoetika.

Borhes, H. L. (2006) Vavilonska biblioteka : Beograd : PAIDEA.

Živković, Z. (2002) Biblioteka: Beograd : Plato.

Andrić, I. (1989). Knjiga, Kula, Deca i druge pripovetke. Priredio Radovan Vučković : Sarajevo : Svjetlost. 
Вранеш, А.(2006) Од рукописа до библиотеке. Појмовник. Београд : Филолошки факултет. Вранеш, А. (2004) Високошколске библиотеке. Београд : Универзитетска библиотека „Светозар Марковић“.

Вранеш, А.; Марковић Љ.(2013) Од рукописа до библиотеке. Појмовник. 3. допуњено и измењено издање : Београд : Филолошки факултет.

Lotman, J. M. (1976). Struktura umetničkog teksta. Prevod i predgovor Novica Petković: Beograd : Nolit.

Bašlar, G. (2005). Poetika prostora. Prevod s francuskog Frida Filipović: Beograd : B. Kukić; Čačak : Gradac.

Детелић, М. (1992). Митски простор и епика. Београд : САНУ.

Кабачек, О.Л. (2009). Краљ бескрајног простора: Хорхе Луис Борхес, песник и фрилозоф библиотеке Библиотека као огледало васељене: огледи из савремене руске науке о библиотекарству. Прир. Добрило Аранитовић: Београд : Службени гласник; Инђија : Народна библиотека „Ђорђе Натошевић“.

Bendžamin, E. (2011). Filozofija arhitekture. Preveo s engleskog Živojin Bata Kara Pešić: Beograd : Clio.

Perović, M.R. (2009). Antologija Teorija arhitekture XX veka: Beograd : Građevinska knjiga. Milosavljević, R. (2004). Pojmovnik : arhitektura, enterijer, dizajn, primenjena umetnost : Beograd : Orion art Stiven Holl

Grosz, E. (2001). Arhitecture form the Outside : Essays on virtual and real Space : Cambrige, The MIT Press

Eisenman, P. (1998). The End of the Classical; The End of the Begining; The End of the End u: Michael Hay (ed.): Arhitecture Theory since 1968, Cambrige The MIT Press.

\section{Ana Ivković}

\section{DIALOGUE OF REAL AND IRRATIONAL}

\section{Summary}

The theme of this paper is to examine the real and imaginary space of libraries from the aspect of architecture as a humanistic science and literature. Spatiality is regarded as an object of interdisciplinary research and as a place of permeation of seemingly different aspects and the establishment of intercultural dialogue among them. Through comparative research and examples of literature and architectural practice, it is sought to answer the question of the extent to which architecture can create space for art, and art to create a space for architecture, and whether there are boundaries between these spaces.

Key words: Libraries, space, interdisciplinarity, culture, architecture, literature 